\title{
Effect of Packaging Materials on Post Harvest Quality of Avocado (Persea Americana) at Wolaita Sodo University in , Ethiopia
}

\author{
Gebre Garmame \\ College of Agriculture, Bulle Hora University, P.O.BOX : 138, Ethiopia \\ Geletaw Kebede \\ College of Agriculture, Department of horticulture, Wolaita Sodo University, P.O.BOX: 138, Wolaita Sodo, \\ Ethiopia
}

\begin{abstract}
The experiment was conducted in laboratory in April 2016 at Wolaita Sodo University, Ethiopia .The objectives of the study were to evaluate the effect of different packaging materials on post harvest quality of avocado fruit and to identify the best packaging materials. The treatment was contain four packaging materials viz, control (floor), dried banana leaf, carton plus newspaper and plastic polyethylene. The experiment was laid out in complete block design with three replications. Data were recorded on post harvest qualiy parameters such as total soluble sugar, total weight loss, decay percentage, titratable acidity and shelf life assessment and analyzed by using statistical software. The result showed that there were a significant difference among all used packaging materials on total soluble sugar and decay percentage, while there were no significant difference among carton plus newspaper and dried banana leaf on total weight loss, titratable acidity and shelf life assessment. Avocado fruit packed in plastic polyethylene has the most long shelf life (14days) than packed in cardboard plus newspaper (10days), dried banana leaf (9days) and floor (control)(6).It can be concluded that avocado fruit stored in plastic polyethene bag prolong the shelf life of avocado than other packaging materials. so, plastic polyethylene bag was recommended. Due to the limitation of our laboratory materials we have used only four treatments; it would be advisable to repeat the experiment by using additional packaging materials to come up a comprehensive recommendation.
\end{abstract}

Keywords: Avocado, packaging materials, post harvest quality parameters

DOI: $10.7176 / \mathrm{JNSR} / 12-22-01$

Publication date: November $30^{\text {th }} 2021$

\section{INTRODUCTION}

Suitable environmental condition on this subject is also hard to find one thing is certain the influenced of climate on avocado growing can only be diseased in relation to the ecological races parlor an (1970) has made a comparison between several areas from Toluca. Mexico ( $19^{\circ} \mathrm{N}$ elevation $\left.2-67 \mathrm{~m}\right)$ to senca Marta, Colombia $\left(11^{\circ} \mathrm{N}\right.$ sea level).Average temperature range from $12.80 \mathrm{c}$ to $28.3^{\circ} \mathrm{c}$ and rain fall was moderate $(665 \mathrm{mmand} 1475 \mathrm{~mm})$ both the dry season was well marked. In contrast to mango and cashew nut the bloom in avocado is not harmed by rain unless it persists fora month more (wolfet al, 1969). More details on the influence of climate on bloom are provided by Auberet al, 1972)

Avocado fruit has been very nutritious fruit containing 3 to 30 per cent- oil similar in composition to olive oil much vitamin A and reasonable quantities of vitamins B and C.Reduce ethylene production and respiration, respiratory activities, better flavor retention slower softening rates slower green color less and maintenance of organization levels were noticed positive effect or result undesirable when more extreme oxygen atmosphere are used in attempts to extend storage life. These undesirable responses consist mainly of discoloration and off flavor development. The relationship between gas exchange rates and rates of quality less has been much more complex. Much research has been one to defines optimum condition for many fresh food products (Moftoonazod, and Rama, wane, 2008) shelf life represent the period of time through with food product remains state to eat and retains its essential story properties and complies with the labels nutrition as declaration (Doughier et al: 2007) many produced have a limited shelf life because as soon as they are produced, changes in their whole sameness begin the occur and after some period, the products losses its effectiveness and therefore must be pulled from the shelf. Even though varies research were conducted about packing materials to proper handling of avocado, there was no concrete recommendation that indicate which one is best packing materials. Hence, avocado is a climacteric fruit it require further physical and chemical change after harvesting. Due use improper packing materials post harvest loss of avocado is higher in Wolaita Zone, southern Ethiopia. Therefore this research was conducted at Wolaita Sodo University with the following objectives: to this research was to identify the best packaging materials for post quality parameter of avocado and to analysis the response of harvested product of avocado to different packaging materials. 


\section{MATERIALS AND METHODS}

\subsection{Description of the Study Area}

The experimental study was carried out during April 25 up to May 09/2016 at WolaitaSodo University horticulture laboratory to find out the effect of different packaging materials on shelf life of avocado fruits. The experimental site is located in southern part of Ethiopia about $390 \mathrm{~km}$ far from Addis Ababa and it located geographically at altitude of $1800 \mathrm{~m}$ asl, $6049 \mathrm{~N}$ and $37045^{\prime} \mathrm{E}$ with annual mean temperature and rain fall of 200c and $1212 \mathrm{~mm}$ respectively (WSU student hand book, 2009).

\subsection{Experimental Materials}

Materials have been used for conducting this experiment was avocado fruits, flour, straw, card board (carton), plastic poly ethylene, refractor meter, water container(smallest one ), Pencil, notebook ,pen, scientific calculator, paper, marker, binder, and sensitive balance.

\subsection{Treatment and Experimental Design}

The experiment was laid out in a complete randomized design with three replication and four treatments (flour, straw, card board (carton), and plastic poly ethylene bag).

\subsection{Experiment Procedure}

Physiologically well matured, and cleaned local avocado fruits were collected from available farm garden. The packing materials were collected from market and the collected samples were also assigned and packed with each packaging materials in the horticulture laboratory. A single sample was consisted of twelve fruit.

\subsection{Data to Be Collected}

Data was collected on each packaged materials between the gap of two days on each sampling data ,a sample of 5 avocado fruits in each treatment was taken randomly for assessment. Data was recorded at two days interval over the storage period.

A/ Shelf life assessment

B/Total soluble solid (TSS)

Representative samples juice was prepared and measured by using a hand refractor meter.

C/ Weight loss (WL)

The weight of the avocado fruit sample with in treatments was measured by using sensitive balance and is expressing in grams within two days interval after ten days final weight loss obtained and \% weight loss was collected by

Percentage of weight loss $=[($ initial Weight - final weight $) /$ initial weight $] \times 100$

$\mathrm{D} /$ Decay percentage (DP)

Any decay during the storage time was assessed and decay percentage was identified by $\mathrm{DP}=(\mathrm{ND} / \mathrm{NM}) 100 \%$, where $\mathrm{ND}=$ no of decay fruit, $\mathrm{NM}=$ no unmarketable fruit

E/ Titratable Acidity

It was determined by taking representative sample of avocado using a standard solution of sodium hydroxide and calculated as

Titratable acidity $=\underline{\text { titer } \times 0.1 \mathrm{Na} \times 0.67} \times 100 \%$

\subsection{Data analysis}

For all responses, the normal distribution and constant variance assumptions on the error terms were verified by examining the residual (Montgomery, 2009), analysis of variance (ANOVA) was done using SAS version 9.2 statistical software (SAS institute, 2008). To asses, the different among treatment mean separation will carry out using least significant difference (LSD) at 5\%.

\section{RESULT AND DISCUSSION}

From this experiment total soluble sugar, total weight loss percentage, decayed percentage, titratable acidity and shelf life of avocado attributes were significantly affected $(\mathrm{p}<0.05)$ among the treatments. The observed results are presented and discussed as follows. 
Table 1.Effect of packaging materials on titratable acidity, Decay (\%), total soluble sugar (Brix), total weight loss (\%) and shelf life assessment of avocado.

\begin{tabular}{|c|c|c|c|c|c|c|}
\hline \multirow[t]{2}{*}{ S.No. } & \multicolumn{6}{|c|}{ Parameters } \\
\hline & $\begin{array}{l}\text { Packaging } \\
\text { materials }\end{array}$ & $\begin{array}{l}\text { Titratable acidity } \\
(\%)\end{array}$ & Decay (\%) & $\begin{array}{l}\text { Total soluble } \\
\text { sugar (Brix) }\end{array}$ & $\begin{array}{l}\text { Total weight } \\
\text { loss }(\%)\end{array}$ & $\begin{array}{l}\text { Shelf life } \\
\text { assessment } \\
\text { (day) }\end{array}$ \\
\hline 1 & Plastic & $0.78^{a}$ & $53.00^{\mathrm{d}}$ & $26.90^{\mathrm{a}}$ & $4.00^{c}$ & $14^{\mathrm{a}}$ \\
\hline 2 & $\begin{array}{l}\text { Carton plus } \\
\text { news paper }\end{array}$ & $0.57^{\mathrm{b}}$ & $64.00^{c}$ & $22.30^{\mathrm{b}}$ & $15.33^{b}$ & $10^{\mathrm{b}}$ \\
\hline 3 & $\begin{array}{l}\text { Dried Banana } \\
\text { leaf }\end{array}$ & $0.54^{\mathrm{b}}$ & $72.00^{\mathrm{b}}$ & $18.00^{\mathrm{c}}$ & $16.33^{b}$ & $9^{b}$ \\
\hline 4 & control & $0.34^{c}$ & $79.00^{\mathrm{a}}$ & $8.67^{\mathrm{d}}$ & $20.83^{a}$ & $6^{c}$ \\
\hline & LSD & 0.0943 & 6.5224 & 2.6129 & 1.2735 & 1.2154 \\
\hline & CV (\%) & 8.97 & 5.17 & 7.31 & 4.788 & 6.455 \\
\hline
\end{tabular}

Lsd= least significant difference among treatments, $\mathrm{CV}=$ Coefficient of variation. Means with the same letter within the same column are not significant difference at $\mathrm{P}<0.05$

\subsection{Titratable acidity}

The analysis of variance showed that there was a significant difference $(p<0.05)$ in titratable acidity $($ Appendix 1$)$ among the treatments. The highest $(0.78) \mathrm{t}$ mean titratable acidity was observed from plastic polyethylene. On the other hand, the smallest (0.34) mean of titratable acidity was observed from avocado stored on the floor (Table $1)$.

Generally, the highest titratable acidity was obtained from the observation that packed in plastic polyethylene bag which can lower the concentration of $0_{2}$ (oxygen) and higher the concentration of $\mathrm{co}_{2}$ (carbon dioxide) results in a reduction of PH to form an acidic medium (Lange and Kader, 1997).

Also this experiment was agreed with Folcroft and Kadar (1999) reported that avocado exposed to higher concentration of carbon dioxide exhibited increased PH and decreased level of titratable acidity. This explains packaging materials those have lower titratable acidity (floor, dried banana leaf and cardboard plus newspaper respectively (Table 1).

\subsection{Decay percentage}

The analysis of variance showed that there was a significant $(\mathrm{p}<0.05)$ different in decay percentage (Appendix 2$)$ among the treatments. The highest (79.00) mean decay percentage was observed from avocado stored on the floor (control) and Dried banana leaf $\left(72.00^{\mathrm{b}}\right)$ being followed by card board plus newspaper (64.00c) (Table 1). On the other hand, the smallest (53.00). Mean decay percentage was observed from avocado stored or packaged in the plastic polyethylene

Result of this experiment should that decay percentage of avocado fruits was influenced by the packaging material. In general, increasing the rate of respiration enhances the amount of decaying. Avocado packed in plastic polyethylene bag exhibited delayed softening and increase shelf life. This is agreed with Thompson etal, 1971) and reduced the effect of chilling injury (persist. etal, 1994); Meiretal. 1997).

\subsection{Total soluble sugar}

The analysis of variance should that there was significant different $(p<0.05)$ for total soluble sugar (Appendix 3 ) among the treatments. The highest mean of total soluble sugar was observed from the observation which was packed in plastic polyethylene (26.90a) and cardboard plus newspaper (22.30b) respectively. On the other hand, the smallest mean total soluble sugar was observed from avocado stored on the floor (8.67) and dried banana leaf (18.00c) respectively as showed above )(table 3). This result is agreement with (liv, et al, and 2002) found a decrease sugars during the progression of the ripening and degree of water loss. Plastic polyethylene bag material displayed more suitable modified atmospheric pressure conditions of low oxygen and high carbon dioxide and decreases the rate of respiration. As the rate of respiration decreased/ total soluble sugar amount is slowly decreased with time going (Xiao and Kyoto, 2001).

\subsection{Weight Loss}

The effect of different packaging materials on the average weight loss of avocado fruit was significant difference between treatments in weight loss at the stored period (Appendix 4). The smallest weight loss was recorded by treatment plastic polyethylene bag (4.00c) and the largest weight loss recorded by treatment (control) (20.83). This results is in agreement with the various finding by Stanly (1995) in which significant increase in fruit weight loss was showed as ripening progressed from mature green to red ripe storage period advances could be associated with increased rate of respiration loss of moisture. In general, post harvest water loss has detrimental 
effect on avocado $\mathrm{s}$ and water loss or weight loss leads to accelerated ripening and a higher degree of physiological disorders (johns ton and Banks, 1996).

\subsection{Shelf life Assessment}

The shelf life of avocado were showed that there was significant $(\mathrm{p}<0.05)$ difference among the packaging material or treatments (Appendix table 5). From the treatment plastic polyethylene bag showed the longest shelf (14day), whereas card board plus newspaper $\left(10^{\mathrm{b}}\right.$ day), and dried banana leaf $\left(9^{\mathrm{b}}\right.$ day') were not differ in significant and floor (control) storage received the lowest duration $\left(6^{\mathrm{c}}\right.$ day). Stored in floor occasionally resulted in skin splitting up on ripening. Plastic polyethylene bag were extend stored life of avocado by lowering the rate of respiration through high oxygen and reduced carbon dioxide. This experiment agreed with the finding of (persist etal, 1994) and (Meir etal, 1997) report that storage avocado in plastic polyethylene bag reduced the effect of chilling injury.

Also this experiment agreed with the finding of (Thompson etal, 1997) reported that avocado stored in plastic polyethylene bags exhibited delayed soft and increased shelf life. Similarly agreed with martin 1997 Yahiya and Gonzalez-Aguilar 1998; Berries 2002 Her top etal 2009 value- Guadarrama etal 2014 managara;etal, 2009 ) reports that plastic polyethylene bag suppresses respiration and ethylene information there by promoting a longer avocado shelf life.

\section{SUMMARY AND CONCLUSION}

Avocado fruit has been very nutritious fruit containing 3 to 30 percent- oil similar in composition to olive oil much vitamin $\mathrm{A}$ and reasonable quantities of vitamins $\mathrm{B}$ and $\mathrm{C}$ Avocado oils is in great demand for the peroration of cosmetics according to people.Avocado fruits have been affected by different packaging materials. Avocado fruits have appropriate high requirement of packaging material. The basic functions of packaging material are for storage, preservation, protection for prolonged periods of time and enhanced quality of avocados.

In general, the result of this study revealed that the effect of packaging material should statistically significant difference on shelf life of avocado. From the selected shelf life parameters (total soluble sugar and decay percentage) were significantly different among all treatments (floor, cardboard plus news paper, dried banana leaf and plastic polyethylene bag).however, weight loss, titratable acidity and shelf life assessment were no significantly affected with cardboard plus newspaper and dried banana leaf. plastic poly ethylene bag was the best one to store compare to other treatments (floor, cardboard plus newspaper and dried banana leaf)because, plastic polyethylene bag material displayed more suitable modified atmosphere condition of low oxygen and high carbon dioxide and decrease the rate of respiration.

The result of this study would invite basic information about varieties of packaging materials which are paramount important to enhance of shelf of avocado. Really, plastic polyethylene bag could be recommended as a best packaging material for long shelf of avocado. It needs further research, with the experiments consisting of even more packaging materials should be conducted to arrive at a conclusive recommendation

\section{REFERENCE}

Abbott, JA (1999) quality measurement of fruit and vegetable post-harvest Biology andtechnology 15(3): 207210.

Adams JB, Brown HM (2007). Discoloration in raw and processed fruits and vegetables. Crit. Rev. Food Sci. Notre. 47(3):319-333.

Adaro I, Gazette S (1974). Water-deficit stress, ethylene production and ripening in avocado fruits. Plant Physiol. 53(1):45-46.

Aguilar-Mendez MA, Martin-Martinez ES, Tomas SA, Cruz-OreA, Jaime-Fonseca MR (2008).Gelatin-starch films: Physicochemical properties and their application in extending the post-harvest shelf life of avocado (PersiaAmericana). J. Sci. Food Agric. 88(2):185-193.

Analsnow dons (1990) post-harvest disease and disorder of fruit and vegetable London. Ashton OBO, Wong M, McGhie TK, Vat her R, Wang Y, Requejo-Jackman C, Ramankutty P, Woolf AB (2006). Pigments in avocado tissue and oil. J. Agric. Food Chem. 54(26):10151-10158.

Arcata-Vazquez I, Chenoa-Perez JJ, de Jesus Pere-Flores M, Calderon Dominguez G, Moreno-Armendáriz MA, Salvo H, Godoy- Calderon S, Queued R, Gutiérrez-Lopez G (2011). Image processing applied to classification of avocado variety Hass (Persia Americana Mill.) during the ripening process. Food Bioprocess. Technol. 4(7):1307-1313.

Ashton OBO, Wong M, McGhie TK, vat her R, Wang Y, Requejo-Jackman C, Ramankutty P, Woolf AB (2006). Pigments in avocado tissue and oil. J. Agric. Food Chem. 54(26):10151-10158.

Banks NH, Cutting JGM, Nicholson SE (1997). Approaches to optimizing surface coatings for fruits.New Zeal. J. Crop Hort. Sci. 25(3):261-272.

Brayed EA (2000).Strength properties of avocado pear. J. Agric. Engorges. 76(4):389-397. 
Barrios JD (2002). Development of a dynamically modified atmosphere storage system applied to avocados. Food Sci. Technol. Int. 8(3)162.

Bezuidenhout JJ (1992). Analysis of transit temperature and fruit condition of South African export avocados.South African Avocado Growers’ Association Yearbook 1992 15:39-40.

Blakely RJ (2011).Management of avocado postharvest physiology. Unpublished PhD Dissertation, School of Horticultural Science, University of Natal, Piertmaritzburg, RSA.

Blakely RJ, Bower JP (2009).The importance of maintaining the cold chain for avocado ripening quality. South African Avocado Growers 'Association Yearbook 32:48-52.

Bower JP, Cutting JGM (1987). Some factors affecting post-harvest quality in avocado fruit. South African Avocado Growers' Association Yearbook. 10:143-146. Bower, Tip and cutting J.M (1988). Avocado fruit development and ripening physiology.Horticulture review pp. (229-265).

Brown BI (1972). Isolation of unpleasant flavor compounds in avocado (Persia-Americana). J. Agric. Food Chem. 20(4):753-757. Bower, tip and cutting J.M (1988).Avocado fruit development and ripening physiology.Horticulture review pp. (229-265).

Burdon J, Lulu, N, Yearsley,C, C, Burmeister D, Billing D (2007). The kinetics of acetaldehyde and ethanol accumulation in 'Hass' avocado fruit during induction and recovery from low oxygen and high carbon dioxide conditions. Posh. Biol. Technol. 43(2):207-214.

Chaplin Association of calcium in chilling injury susceptibility of stored avocados. Hortscience 15,154-514.

Chen NJ, Wall MM, Paul RE, Follett PA (2009).Variation in 'Sharwil'avocado maturity during the harvest season and resistance to fruit fly infestation. Hortscience 44(6):1655-1661.

Covey .H.M (1986) chilling injury of crops of tropical origin Hort science 17,162-162.

Cox KA, McGhie TK, White A, Woolf AB (2004). Skin color and pigment changes during ripening of 'Hass' avocado fruit.Posh. Biol. Technol. 31(3):287-294.

Cutting JGM, Wolstenholme BN, Hardy J (1992). Increasing relative maturity alters the base mineralcomposition and phenolic concentration of avocado fruit. J. Hort. Sci. 67(6):761-768.

De Ruck K, Siva Kumar D, Kirsten L (2010). Effect of passive and active modified atmosphere packaging on quality retention of two cultivars of litchi (Litchi Chinese'sSon.). J. Food Qual. 33(1):337-351.

Dodd M, Cronje P, Taylor M, Huysamer M, Fugger F, Lots E, van de Merowe K (2008). A review of the postharvest handling of fruits in South Africa over the past twenty five years. South Afr. J. Plant Soil.27(1):97-116.

Dough or, et al (2007) storage of life enhancement of avocado fruit unpublished Morang dissertation, department of Bio resource engineering mongouniversity,site Anne lee Bellevue, Canada.

Ears IL (1973). Effects of clip vs. snap harvest of avocados on ripening and weight loss. J. Am. Soc. Horticulture. Sci. 98(1):106-108.

Ears IL (1976). Ripening, chilling injury, and respiratory response of 'Hass' and 'Fuertes' avocado fruits at $20^{\circ}$ $\mathrm{C}$ following chilling. J. Amer.Soc. Hort. Sci. 101(5):538-540.

Ears IL (1978). Ripening, respiration, and ethylene production of 'Hass'avocado fruits at 20 to $40^{\circ} \mathrm{C}$. J. Am. Soc. Horticultural Sci. 103(5):576-578. Phallic E (2004).Presto rage hot water treatments (immersion, rinsing and brushing). Posh. Biol. Technol. 32(2):125-134.

Eckstein GJ (1995). Handling Guidelines for Avocado -1995 Season. South African Avocado Growers' Association Yearbook 18:111-113.

Eckstein GJ (1999). Handling Procedures for Avocados 1999 Season. South African Avocado Growers' Association Yearbook 22:76-82.

El-Mir M, Gerasopoulos D, Metzidakis I, Canellas AK (2001). Hypoxic acclimation prevents avocado monocarp injury caused by subsequent 2400 Afr. J. Agric. Res.exposure to extreme low oxygen atmospheres. Posth. Biol. Technol 23(3):215-226.

Phallic E (2004).Presto rage hot water treatments (immersion, rinsing and brushing). Posh. Biol. Technol. $32(2): 125-134$

Fang X, Erlbaum A, Sister EC, and Goren R (2000) .Control of ethylene responses in avocado fruit with 1methylcyclopropene. Posh. Biol. Technol. 20(2):143-150.

Ferguson I, Vole R, Woolf A (1999).Preharvest factors affecting physiology disorders of fruit.Posh. Biol. Technol. 15(3):255-262.

Fang X, Erlbaum A, Sister EC, and Goren R (2000) .Control of ethylene responses in avocado fruit with 1methylcyclopropene. Post. Biol. Technol. 20(2):143-150.

Flitsanov U, Mizrahi A, Liber on A, Ackerman M, Zukerman G (2000). Measurement of avocado softening at various temperatures using ultrasound.Post. Biol. Technol. 20(3):279-286.

Florissant P, Ekman JS, Blumenthal C, Glasson B, Conroy J, Helford P (1996). The effects of short heattreatments on the induction of chilling injury in avocado fruit (Persia Americana Mill). Post. Biol. Technol. 
$8(2): 129-141$.

Ferrero MP (2007). Storage life enhancement of avocado fruit. Unpublished MSc (space)Eng. Dissertation, Department of Bio resources Engineering, McGill University, Step-Anne De Bellevue, Canada.

Gamble J, Harked FR, Jaeger SR, White A, Brava C, Beresford M, Stubbing's B, Wohler's M, Hoffman PJ, Marques R, Woolf A (2010). The impact of dry matter, ripeness and internal defects on consumer perceptions of avocado quality and intentions to purchase.post. Biol. Technol. 57(1):35-43.

Garlic K, Scepter M, Kure M (2011). The benefits of processing and packaging.Tern. Food Sci. Technol. 22(23):127-137.

Gerard M, Gobble B (2005). ETHY.A theory of fruit climacteric ethylene emission. Plant Physiol. 139(1):531545.

Get net H, Workneh TS, Woldetsadik K (2011). Effect of maturity stages, variety and storage environment on sugar content of tomato stored in multiple pads evaporative cooler. Afr. J. Bioethanol. 10(80):18481-18492.

Gomez AH, Wang J, Pereira AJ (2005).Impulse response of pear fruit and its relation to Madness-Taylor firmness during storage.Post. Biol. Technol. 35(2):209-215.

Gobble B, Faith D, Soudan, P (1995). Nitrous oxide inhibition of ethylene production in ripening and senescing climacteric fruits.Post. Biol. Technol. 5(4):311-321.

Hagen Maier RD, Shaw PE (1992). Gas permeability of fruit coating waxes. J. Amer. Soc. Hort. Sci. 117(1):105109.

Hatton Jr. TT, Reeder WF (1972). Quality of 'Lula' avocados stored in controlled atmospheres with or without ethylene. J. Am. Soc. Hort. Sci. 97(3):339-341.

Herskovits V, Saggy SI, Pepsis E (2005). Postharvest application of 1-MCP to improve the quality of various avocado cultivars.Post. Biol. Technol. 37(3):252-264.

Hertog MLATM, Nicholson SE, Whitmore K (2003). The effect of modified atmospheres on the rate of quality change in 'Hass' avocado.Post. Biol. Technol. 29(1):41-53.

Hoffman PJ, Jobbing-Decor M (1999). Effect of fruit sampling and handling procedures on the percentage dry matter, fruit mass, ripening and skin color of 'Hass' avocado. J. Hort. Sci. bioethanol. 74(3):277-282.

Hoffman PJ, Jobbing-Decor M, Giles J (2000). Percentage of dry matter and oil content are not reliable indicators of fruit maturity or quality in late-harvested 'Hass' avocado. Hort science 35(4):694-695.

Hoffman PJ, Fuchs Y, Milne DL (2002a). Harvesting, packaging, postharvest technology, transport and processing. In: ed. While, AW, Schaffer, B and Wolstenholme, BN, The Avocado: Botany, Production and Uses, Ch. 14,363-401.CABI Publishing, Wallingford, Oxon.

Hoffman PJ, Stubbing's BA, Adkins MF, Marburg GF, and Woolf AB (2002b). Hot water treatments improve 'Hass' avocado fruit quality after cold disinfestations. post. Biol. Technol. 24(2):183-192.

Hoffman PJ, Stubbing's BA, Adkins MF, Corcoran RJ, White A, Woolf AB (2003). Low temperature conditioning before cold disinfestations improves 'Hass' avocado fruit quality. post. Biol. Technol. 28(1):123-133.

Honshu Whitney GW (2002). Should the California avocado industry consider "snap" harvesting? An overview of the South African avocado industry and planting trees on clonal rootstocks.Avow Research 2(2):1-12.

Holcroft Embower, tip and cutting J.M (1988). Avocado fruit development and ripening physiology.Horticulture review pp. (229-265).

Moftoonazod and roamswane :(2008) quality chilling facing the south African industry, an over view of 2009 south African avocado see south African avocado growth association year book 33, 7-13 .

Rice, R,P. rice louder and Tindal .H. D(1990) fruit and vegetable production in warm tropics MacMillanLondon.

Samson, JA (1986). Tropical fruit longmen groupUK.limited jacksI.D.

Tonga, P.Oand young .R.E (1975).The effect of in dole 3-acetic acid and other growth regulators on the ripening of avocado fruit plant physiology 55,337. 